\title{
Research focus and authorship trends over 40 years of publications by New Zealand Plant Protection
}

\author{
T.M. Stewart \\ Institute of Agriculture and Environment, Massey University, Private Bag 11 222, Palmerston \\ North, New Zealand \\ Corresponding author: $\underline{\text { t.stewart@massey.ac.nz }}$
}

\begin{abstract}
In total, 3053 contributions consisting of papers, research notes and poster abstracts to the New Zealand Plant Protection Society from 1976 to 2015 were analysed for research and authorship trends. The mean number of authors per paper per year increased from 1.8 to 4.3 over this period and institutional collaboration was increasingly common. Proportionally, there was a steady decrease in weed contributions and an increase in those featuring plant pathogens. Control measures shifted from largely chemical solutions for single weed species to more integrated management programmes. The number of papers on weed, pest or disease biology, incidence, spread and impact were fairly constant over this period. The scope of research widened considerably from a largely pastoral and arable focus to include environmental weeds and border biosecurity. Topical research findings and review papers highlight the responsiveness of the plant protection research community to emerging novel issues.
\end{abstract}

Keywords Weeds, pests, pathogens, research trends, scientiometrics

\section{INTRODUCTION}

The origins of the New Zealand Plant Protection Society were at the first national weed conference in 1948. The goal of this first meeting was to bring together all stakeholders involved in the research and management of undesirable plants. The annual meetings were considered a great success by the membership and by 1962, the scope was widened to include vertebrate and invertebrate pests and fungal pathogens. Several name changes and 54 years later, the annual Plant Protection Conference and its published proceedings (now a peer-reviewed scientific journal) remain major sources for research and reporting on the biology and management of weeds, plant pests and plant diseases in New Zealand. Popay (1997) analysed publications and trends over the first half century of the Society's proceedings, showing the changes both in research themes and contributors. This paper shares similar objectives and starts in 1976 when the society and its contributions had settled into the format that endures today. Along with pests and weed contributions, papers and research notes on plant diseases were regularly featured and publications generally conformed to the standards of scientific writing. Also, whereas the previous work examined a sub-sample of publications, this study encompasses all contributions in all years within that timeframe. It reveals the major organisms, the 
environments where they cause problems, themes explored and how research emphasis has changed.

\section{MATERIALS AND METHODS}

All papers, research notes and poster abstracts listed in the annual conference proceedings from 1979 to 2015 were included in the analysis. These are referred to collectively in this study as 'contributions'. The number of authors per contribution was recorded together with their institutional affiliations.

A content analysis (Berelson 1952) was carried out on each publication to group them into categories. The process involved coding (Taylor \& Gibbs 2010) largely based on the title and keywords, but also using the text itself for more information where necessary.

Each contribution was coded under three major groupings: "Agent" (the weed(s), pest(s) or pathogen(s) that the research pertained to); "Environment" (the crop or environment that an agent or agents under study were situated in or relevant to); and "Theme" (e.g. a control procedure, policy, basic biology/ecology, impact assessment etc.). Nvivo software (QSR International 2016) was used to create specific hierarchical code subgroups (called nodes) underneath these three groupings. Individually, the contributions were assessed and allocated to one or more nodes in each group relevant to the topics in the contribution. The number of contributions in selected nodes and sub-nodes of interest were counted and tables and charts produced accordingly. Allocation to nodes within the three main groupings was not always mutually exclusive as a contribution could refer to several specific agents, environments or themes.

The scientific names to most of the common weeds, pests and pathogens cited in this study are provided in Table 1.

\section{RESULTS AND DISCUSSION Contributions, authors and affiliation}

Contributions per year ranged from a low of 48 (1978) to a peak of 123 (1997). The latter was the Plant Protection Society's $50^{\text {th }}$ conference which marked 50 years of New Zealand Plant
Protection. The large number of general papers in 1997 reflects the contributions pertaining to, and celebrating, that event. Since that time annual contributions have varied between 64 and 110 .

One noticeable trend in publication attributes was an increase in the number of authors per contribution (Figure 1). Author numbers per contribution show a steady increase from typically one to two authors in the late 1970s/early 1980s to an average of three or four in 2015 . No papers in 2011 and 2014 contained fewer than two authors and one paper in 2009 and one in 2015 boasted 15 authors! Up to 1996 between $0 \%$ and $22 \%$ of papers published in any one year had two or three institutions represented in the author list. After 1996 this number started to rise dramatically. In 2012 , only $48 \%$ of papers were from a single institution and the years 2012, 2013 and 2015 contained individual papers by authors from up to five institutions. International collaboration has also increased, with $18 \%$ of papers having at least one author affiliated to an overseas institution in 2011 and 2015, compared to practically none up to and including 1982. This may exemplify the leading role New Zealand plays in research internationally. However, an overseas address associated with an author is only a rough proxy for institutional collaboration and may reflect a post-graduate student or scientist with a new job post-project.

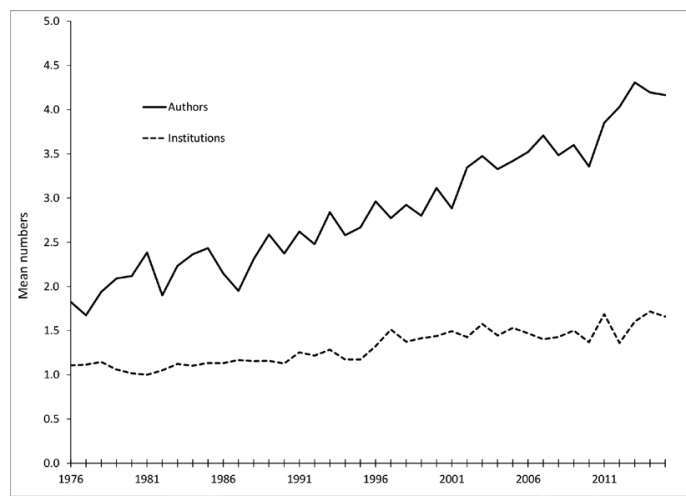

Figure 1 Mean number of authors and institutions collaborating on contributions to the New Zealand Plant Protection Society from 1976 to 2015 . 
Collaborative projects, as reflected by papers authored by many researchers sometimes from different research institutes, are a worldwide trend in the $21^{\text {st }}$ century. Research shows co-authorship amongst scientific papers has been increasing inexorably (Leydesdorff \& Wagner 2008). Collaborative papers provide access to funding, facilities and ideas, facilitating important research networks (Adams 2012). Few scientists nowadays are able to complete a project alone because of the complexity of modern pest issues and it is no surprise therefore that New Zealand Plant Protection reflects this phenomenon.

\section{Agents}

Of the three main agents (i.e. weeds, pests and pathogens) in plant protection, pests and/or their management were the dominant research target over the past 40 years constituting $44.3 \%$ of published work. This figure includes research on beneficial species and micro-organisms that are known to assist with control of particular pests or pest groups. Weeds (25.5\%) were the next highest group followed by pathogens (23.5\%). A small percentage (4.55) focused on issues pertinent to all areas of plant protection (e.g. emerging technologies, policy, strategies etc.) while only $1.5 \%$ investigated organisms which may benefit plant health generally, but are not linked to any

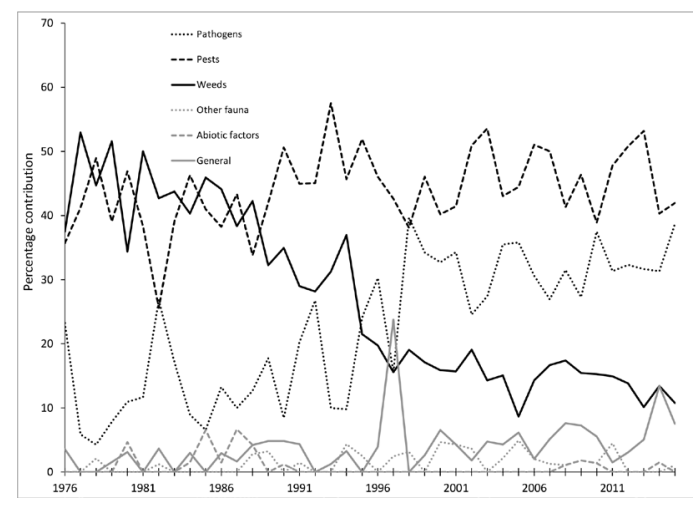

Figure 2 Percentage of contributions pertaining to each main plant protection agent in contributions to the New Zealand Plant Protection Society from 1976 to 2015. particular damaging agents (e.g. earthworms, mychorhizzal fungi etc.). Contributions pertaining to abiotic factors accounted for $0.7 \%$.

Figure 2 shows how the proportion of contributions has changed between plant protection agents over the period 1976 to 2015 . The most striking trend is the decrease in weed research from 53\% of contributions in 1977 to around $11 \%$ in 2015 . In contrast, there is a steady rise of pathogen-related papers with smaller increases in general and other fauna studies. The rise in pathogen-related papers can be attributed to the increasing work on new high-value horticulture crops where diseases are generally more problematic. As a proportion of contributions, pest research overall has remained steady between 33.8 and $57.5 \%$, apart from a dip in 1982 , where a national focus on stripe rust of wheat occurred.

Table 1 shows the top 10 weeds, pests and pathogens investigated during the period of study. Amongst the weeds, gorse has been of sustained interest last century declining to only a single contribution between 2007-2015. Thistles in pasture were also a major focus for control, but papers on this topic have also declined in recent years.

Pasture pests such as grass grub, Argentine stem weevil and porina featured regularly in research contributions during the period under study. Grass grub research was prominent in the 1980s. There were seven contributions in 1979, 1981 and 1983. When the author attended his first Weed and Pest Control Conference in 1981, a common moniker was "The New Zealand gorse and grass grub conference". The figures bear this out! Research in Argentine stem weevil reached a peak in 1994 with 9 contributions on distribution, damage and parasitoid research. However, as with the pasture weeds, there are fewer contributions on these agents or their control techniques recently than there have been in the past. Of the three pests above, in 2014 there was only one contribution (on grass grub) while in 2015 there were three on Argentine stem weevil and one on porina.

The reasons for the decline of research into weeds and pasture pests reflect changing research priorities and in some cases successful 
Table 1 Top ten weeds, pests and diseases pertinent to contributions from 1976 to 2015.

\begin{tabular}{|c|c|c|}
\hline Group & Common Name (Species) & Number \\
\hline \multirow[t]{12}{*}{ Weeds } & Gorse (Ulex europaeus) & 74 \\
\hline & Nodding thistle (Carduus nutans) & 41 \\
\hline & Californian thistle (Cirsium arvense) & 38 \\
\hline & Ragwort (Jacobaea vulgaris) & 29 \\
\hline & Giant Buttercup (Ranunculus acris) & 26 \\
\hline & Wild oats (Avena fatua) & 22 \\
\hline & Barley grass (Critesion spp.) & 13 \\
\hline & Broom (Cytisus scoparius) & 13 \\
\hline & Summer grass (Digitaria sanguinalis) & 12 \\
\hline & Blackberry (Rubus fruticosus) & 10 \\
\hline & Fathen (Chenopodium album) & 10 \\
\hline & Nightshades (Solanum spp.) & 10 \\
\hline \multirow[t]{10}{*}{ Pests } & Light brown apple moth (Epiphyas postvittana) & 102 \\
\hline & Grass grub (Costelytra zealandica) & 103 \\
\hline & Argentine stem weevil (Listronotus bonariensis) & 82 \\
\hline & Clover root weevil (Sitona lepidus) & 53 \\
\hline & Armoured scale insects (Hemiptera: Diaspididae) & 53 \\
\hline & Mealy bugs (Hemiptera: Pseudococcidae) & 37 \\
\hline & Tomato/potato psyllid (Bactericera cockerelli) & 36 \\
\hline & Apple leaf curling midge (Dasineura mali) & 31 \\
\hline & Codling moth (Cydia pomonella) & 28 \\
\hline & Porina (Wiseana spp.) & 27 \\
\hline \multirow[t]{10}{*}{ Diseases } & Grey mould (Botrytis cinerea) & 59 \\
\hline & Black spot in apples (Venturia inaequalis) & 39 \\
\hline & PSA-V in kiwifruit (Pseudomonas syringae pv. actinidiae) & 24 \\
\hline & Stripe rust of wheat (Puccinia striiformis) & 23 \\
\hline & Fireblight in pipfruit (Erwinia amylovora) & 21 \\
\hline & Brown rot of stonefruit (Monilinia fructicola) & 21 \\
\hline & Sclerotinia (Sclerotinia sclerotiorum) & 19 \\
\hline & Camellia flower blight (Ciborinia camelliae) & 18 \\
\hline & Yellow dwarf virus & 17 \\
\hline & White rot of onions (Sclerotium cepivorum) & 15 \\
\hline
\end{tabular}

control strategies. For example, Argentine stem weevil significance had been reduced due to endophyte-conferred resistance in grasses and control by the parasitoid, Microctonus hyperodae, at least up until relatively recently (Popay et al. 2011).

Many of the other top ten pests and pathogens, such as botrytis, light brown apple moth, armoured scale, mealy bugs, apple leaf curling midge and codling moth reflect the large amount of activity in the search for Integrated Pest Management solutions in pipfruit and grapes since the late 1980s (e.g. Walker et al. 2015). These remain important topics that still continue to be addressed. Others reflect activity which occurred around newly arrived problems such as clover root weevil, tomato/potato psyllid, PSA-V in kiwifruit, stripe rust of wheat and camellia flower blight. 
Table 2 Top 10 crops or plant groupings from 1976 to 2015.

\begin{tabular}{lc}
\hline Crop & Contributions \\
\hline Pasture & 728 \\
Pipfruit & 293 \\
Kiwifruit & 175 \\
Cereals & 169 \\
Pine forests & 99 \\
Grapes & 98 \\
Stonefruit & 89 \\
Potato & 78 \\
Brassicas & 78 \\
Maize and sweetcorn & 73 \\
\hline
\end{tabular}

\section{Environment}

Contributions to the 'environment' node were separated into three main groups i.e. managed plant communities (crops, pasture, amenity and turf), non-crop environments (native forests, urban environments, open areas, national parks, high country scrublands, wetlands etc.) and general contributions which were not situation-specific such as policy papers, new technology developments and current issues. Contributions concerning managed plant communities (87\%) dominated general papers $(7 \%)$ and non-crop environments $(6 \%)$. Of the non-crop environments, native forests received the greatest emphasis over this period (74 contributions). These largely dealt with possum, weed and wasp control and, lately, Kauri dieback disease (Phytophthora agathidicida). Natural grassland or open areas registered 46 contributions, mainly pertaining to environmental weeds. Note that in general gorse, broom and blackberry studies were placed into a pasture subcategory within "managed plant communities", unless the study specifically dealt with non-agricultural areas. Wetlands and aquatic environments saw 21 contributions; mostly dealing with aquatic weeds and 20 contributions were counted in the urban category e.g. non-plant pests (wasps, cockroaches, ant, termites, mosquitoes) and weed control. Other contributions in single figures under non-crop environments included maggot problems in dairy sheds, weed control in railway tracks, sand dunes and riparian zones, midge control in sewage ponds, and mould mites in tissue culture facilities.

Managed plant communities were partitioned into amenity, arable, forestry, cut flowers, fruit, nursery, pasture, protected/hydroponic, shelterbelts, tropical, turf and general. The last category held contributions that had relevance to all managed plant communities, but not non-crop environments e.g. some on spray application technology and pesticide residues. Over the study period, problems in fruit crops scored the highest (29\%) of the managed crops sub-groupings, with arable crops (including vegetables) $(28 \%)$ and pasture (26\%) similarly common. Other categories constitute less than 5\% each.

Each managed plant community subcategory listed above was broken down still further to individual crops or plant groupings. Some were resolved to individual species (e.g. potato (Solanum tuberosum)). However others pertained to a grouping of related plants (e.g. stonefruit), or plants that are generally managed together (e.g. pasture). These groupings reflect a recognised industry sector. Table 2 shows the top 10 crop or plant groupings over the period of study. Dominant was pasture and pipfruit, with kiwifruit and cereals also prominent.

Over the study period there was a gradual decline in contributions on pasture problems and an increase in work targeting horticultural issues, especially in export crops such as apples, kiwifruit and grapes. Research contributions on potatoes have increased since 2008 due to the need to control tomato/potato psyllid (Bactericera cockerelli). In 2013 there were 12 contributions relevant to this pest.

\section{Themes}

The major themes identified from coding are shown in Table 3. Many papers had several themes and so were scored in more than one. For example, 27 of the contributions in "Pest weed and pathogen biology, incidence, spread and impact" are shared with "Biosecurity" as they focused on newly 
Table 3 Major themes of Journal publications

Theme

Contributions

Control

2086

- biological control, chemical control (including pest pheromones for mating disruption and supervised spraying), physical and cultural control and plant resistance and economics of control.

Pest, weed and pathogen biology, incidence, spread and impact

Biosecurity

- curtailment and eradication, diagnosis and identification, incursion investigations, information systems policy, post entry quarantine and treatment, risk analysis, surveillance and export treatments

Monitoring and prediction

Diagnosis and identification

IPM programmes

- Featured programmes that had an element of monitoring and combine more than one control technique and/or more than one damaging agent

Postharvest

General methods

- $\quad$ tools and techniques e.g. precision agriculture, systems evaluation, culture and rearing techniques, damage and dispersal assessment, pesticide risk assessment and microscopy

Policy and regulation

Organic growing

Reviews and discussion papers $\quad 24$

$\begin{array}{ll}\text { Other input effects } & 17\end{array}$

- fertilisers and other amendments

Farmer and industry surveys

Growth promoters-modifiers

Economic cost of an existing damaging agent

- Established problems only, not biosecurity threats or incursions.

Education and training

General information systems 2

established weeds, pests and pathogens. Similarly, some of the discussion papers may have alluded to particular control procedures or biosecurity so they were also scored in those respective themes. Many postharvest treatments were also counted within "Control" and "Biosecurity".

As expected, there is an overwhelming dominance of contributions pertaining to control procedures. Figure 3 partitions these into sub-themes by main target groups, while Figure 4 displays changes in sub-themes over time.

Numerous papers on predators, parasites and microbial pathogens of pests (376) dominated "Biological Control" studies (574). Contributions on biological control on weeds (101) or pathogens (94) were about equal while the "General" category was concerned with just three discussion / review papers on the subject.

In contrast, contributions on weed control using herbicides (503) dominated the "Chemical Control" theme (1328) although insecticide studies came a close second (465). The "General" category (107) in this theme involved contributions on adjuvants, application and deposition, interactions, pesticide risk reduction, databases and rating 


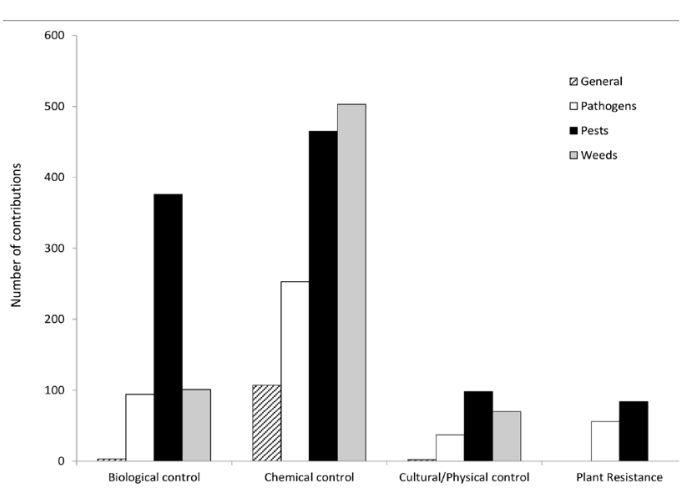

Figure 3 Total number of contributions to the New Zealand Plant Protection Society on biological, chemical, and cultural/physical control and plant resistance themes from 1976 to 2015 .

systems, record keeping, residues and software.

Pest treatments (98) dominated "Cultural/ Physical Control” techniques (207). The latter included grazing management, cultivation, heat treatments, controlled atmosphere, irradiation and washing and physical barriers. Weed contributions (70) in this subcategory explored a mix of grazing management, cultivation and fallow, mulches, mechanical weeding, solarisation, undersowing, mowing and competition. For pathogens (37), techniques included controlled atmosphere, crop rotation, heat, washing, mulches, physical barriers and soil amendments. It should be noted that addition of natural and artificial fertilizers to aid plant competition and facilitate biological breakdown is also scored in this theme. The two contributions under "General" here dealt with soil management and biological succession for whole crop systems.

The theme of "Plant Resistance" (140) included contributions on varieties/cultivars, transgenic plants, induced resistance, mechanism studies and resistance through associations with other organisms such as mycorrizha and endophytes. Endophyte studies, mostly against Argentine stem weevil dominated the pest resistance studies contributing 45 of a total of 56 contributions.

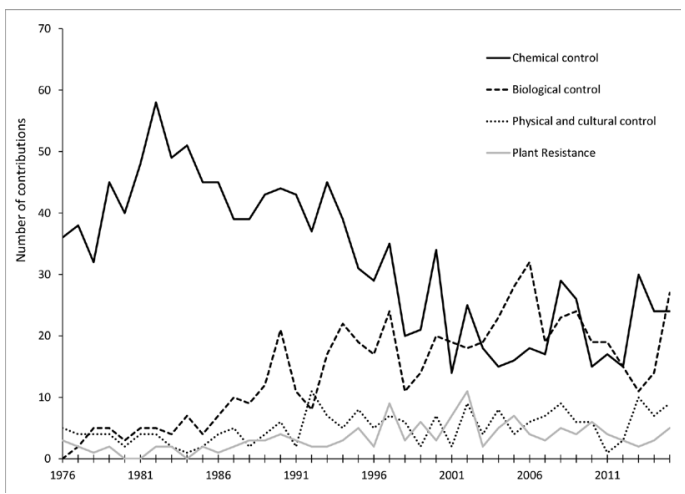

Figure 4 Percentage of contributions to the New Zealand Plant Protection Society pertaining to chemical, biological, physical/cultural and plant resistance themes from 1976 to 2015.

Trends in "Control" show a move away from contributions based on chemical control (Figure 4), a trend that has been noted elsewhere (Stejskal \& Aulicky, 2003). The slide occurred most dramatically with herbicide studies from 1995 onwards. Prior to that period the mean number of papers was 20.2. From 1995 to the present day the mean number over that period was 5.6. This also coincides with a reduction in the level of weed research generally. The rise in biological control contributions over the past decades was largely aimed at the management of pests, and (more unevenly) pathogens. In 1976, there were zero contributions in pest biological control reaching a peak of 25 in 2006. In that year, there were only five contributions on insecticide control and only two the previous year. Much of the control research contributed to IPM programmes in fruit and protected crops.

Regarding some of the other major themes, studies on "Pest, weed and pathogen biology, incidence, spread and impact" were steady contributors during the period under study. Looking at the trends over time there were two plateaus. One was 1976 to 1993 when the mean number of contributions was 9.2. Contributions jumped in 1994 showing a mean 
number of 20.6 from that year through to 2015 .

"Organics" appeared in 1989 following increasing interest of this method of crop production. There were five contributions in that year and four in 1990. Numbers then declined to one or zero until a period of activity (two to five contributions/year) from 2000 to 2007.

Contributions on "Diagnosis and Identification" not unexpectedly favoured pathogens, while contributions on Monitoring and Prediction mostly considered pests.

One clear trend over this period was the rise in contributions on "Biosecurity". Each decade from the 1970s to the present day has seen notable incursions, with a number of serious pests, pathogens and weeds managing to establish themselves. The real and potential impact on New Zealand's trade of these incursions has been met with an increase in research, which is reflected in this study. Prior to 1986, only one paper in 1976 was scored for this theme. From 1986 to 2001 a few biosecurity papers did appear, typically one or two a year. However, 2002 saw a large jump in contributions (16) and this has continued with an annual average of 11 contributions on this theme from 2002 to 2015 . Biosecurity has received increasing attention from producers, government and general public alike as New Zealand increases its volumes of imports/exports, enters transparent trade agreements and tourist numbers expand. The Biosecurity Act passed in 1993 (Anon. 2016) supports the systematic protection of New Zealand's valued biological systems from the harmful effects of exotic damaging organisms and this legislation provides a research focus.

\section{CONCLUSIONS}

The papers, posters and research notes provide in the Plant Protection journal provide a relevant snapshot of the issues and problems in plant protection research over a 40 year period.

The data show the proportion of weed contributions declined while pathogens increased. Also, contributions have moved from largely chemical control and advisory papers written by one or two authors, to collaborative efforts addressing a wide range of issues and themes of increasing diversity and complexity. Contributions quickly appeared when new pests, diseases or weeds increased in prominence. New technologies have been highlighted as they have become available. Niche areas with export potential, such as Organics, have been explored as demand and interest increased. Contributions also record a rich history of stepwise development for the IPM components of laudable whole crop programmes such as Apple Futures (Walker et al. 2015). For a Society, it is 40 years of which to be very proud.

\section{ACKNOWLEDGEMENTS}

The author wishes to thank Robert Southward (Massey University) who reviewed this manuscript.

\section{REFERENCES}

Adams J 2012. Collaborations: The rise of research networks. Nature 490: 335-336.

Anonymous 2016. Biosecurity Act 1993 http://www.legislation.govt.nz/act/ public/1993/0095/latest/DLM314623.html (accessed May, 2015).

Berelson B 1952. Content analysis in communications research. Free Press, Glencoe, IL. 220 p.

Leydesdorff L, Wagner CS 2008. International collaboration in science and the formation of a core group. Journal of Informetrics 2 (4): 317-325.

Popay AJ 1997. The history of Plant Protection in New Zealand: A survey of conference proceedings. Proceedings of the $50^{\text {th }}$ New Zealand Plant Protection Conference: 344354.

Popay AJ, McNeill MR, Goldson SL, Ferguson CM 2011. The current status of Argentine stem weevil (Listronotus bonariensis) as a pest in the North Island in New Zealand. New Zealand Plant Protection 64: 55-63.

QSR International 2016. Nvivo 11 for Windows http://www.qsrinternational.com/product/ 
nvivo11-for-windows (accessed 17th May, 2016)

Stejskal A, Aulicky R 2003. Scientometrical Analysis of the Journal Plant Protection Science in 1950-2002. Plant Protection Science 39 (3): 109-115.

Taylor C, Gibbs GR 2010. How and what to code http://onlineqda.hud.ac.uk/Intro QDA/ how what to code.php (accessed 15th April, 2015).
Walker JTS, Park NM, Butcher MR 2015. Apple Futures: New Zealand's low pesticide residue apple production program. New Zealand Plant Protection 68: 282-290. 